Published in final edited form as:

Curr Protoc Stem Cell Biol. ; 32: 4A.8.1-4A.8.17. doi:10.1002/9780470151808.sc04a08s32.

\title{
Teratoma Formation: A Tool for Monitoring Pluripotency in Stem Cell Research
}

\author{
Raman V. Nelakanti ${ }^{1,2,3}$, Nigel G. Kooreman ${ }^{1,2,3,4}$, and Joseph C. $\mathbf{W u}^{1,2,3}$ \\ ${ }^{1}$ Stanford Cardiovascular Institute ${ }^{2}$ Departments of Medicine and Radiology (Molecular Imaging \\ Program) ${ }^{3}$ Institute of Stem Cell Biology and Regenerative Medicine, Stanford, California \\ 94305-5454, USA 4Department of Vascular Surgery, Leiden University Medical Center, Leiden, \\ The Netherlands
}

\begin{abstract}
This unit describes protocols for evaluating the pluripotency of embryonic and induced pluripotent stem cells by a teratoma formation assay. Cells are prepared for injection and transplanted into immunodeficient mice at the gastrocnemius muscle, a site well suited for teratoma growth and surgical access. Teratomas that form from the cell transplants are explanted, fixed in paraformaldehyde, and embedded in paraffin. These preserved samples are sectioned, stained, and analyzed. Pluripotency of a cell line is confirmed by whether the teratoma contains tissues derived from each of the embryonic germ layers: endoderm, mesoderm, and ectoderm. Alternatively, explanted and fixed teratomas can be cryopreserved for immunohistochemistry. Antibody staining can allow for a more detailed identification of specific tissue types present in teratoma samples.
\end{abstract}

\section{Keywords}

pluripotent stem cell; induced pluripotent stem cell; embryonic stem cell; teratoma; pluripotency; tumorigenicity

\section{INTRODUCTION}

Pluripotent stem cells (PSCs) are at the forefront of current medical innovation and are instrumental in fields ranging from regenerative medicine to disease modeling (Karlsson et al., 2009; Robinton and Daley, 2012; Lan et al., 2013). Pluripotent cells, such as embryonic stem cells (ESCs) and induced pluripotent stem cells (iPSCs), have the potential to differentiate into tissues from all three germ layers (Thomson et al., 1998; Takahashi and Yamanaka, 2006). With any new human or mouse PSC line, it is important to characterize the line and confirm pluripotency before proceeding with downstream experiments. Some of the tools to characterize these PSCs include quantitative PCR and immunofluorescence staining, which look for the upregulation of pluripotency genes such as Oct4, Sox2, c-Myc,

Contact information: 265 Campus Drive, Rm G1120B, Stanford, CA 94305-5454

Raman V. Nelakanti: 408-242-5987, ramann@stanford.edu

Nigel G. Kooreman: 650-284-6461, kooreman@stanford.edu

Joseph C. Wu*: Ph: 650-736-2246, Fax: 650-736-0234, joewu@stanford.edu 
KLF4, and Nanog (Noaksson et al., 2005; Bhattacharya et al., 2004; Masui et al., 2007; Kim et al., 2008; Mitsui et al., 2003). Recent assays subscribe to a holistic approach to PSC classification by using bioinformatics to identify patterns in microarray and DNA methylation data from sets of PSC lines (Müller et al., 2011; Bock et al., 2011). Other methods look for reasons for exclusion, such as finding genomic abnormalities by gene expression karyotyping (Ben-David et al., 2013). The traditional gold standard, however, is assessing the ability of these PSCs to form tissues from all three germ layers in vivo in the form of an encapsulated tumor called a teratoma (Brivanlou et al., 2003; Hentze et al., 2009).

Human and mouse PSCs that are transplanted in an immunodeficient mouse will spontaneously differentiate to form a teratoma comprised of all three germ layers (Kooreman and $\mathrm{Wu}, 2010$ ). This protocol describes the intra-muscular injection of PSCs in the gastrocnemius muscle, which is easy to access and highly vascularized. Teratoma explantation from the hind limb requires only simple surgical techniques and is accessible to researchers at any level of expertise. After teratoma growth and explantation, the tissue samples are fixed and embedded in paraffin or cryopreserved. Paraffin embedding followed by sectioning and hematoxylin and eosin (H\&E) staining is the standard for verifying the formation of the three germ layers in the explanted teratoma tissue. Alternatively, the samples can be cryopreserved for immunohistochemistry.

This unit provides a detailed description for performing a teratoma assay to establish the pluripotency of a PSC line in a murine model. First, we will illustrate the surgical procedure for cell transplantation in the gastrocnemius muscle (Basic Protocol 1) and the preparation of the PSCs before transplantation (Support Protocol 1). Then, we will describe the explantation and processing of the teratomas by fixation and paraffin embedding (Basic Protocol 2) or cryopreservation (Alternate Protocol 2). Finally, we will conclude with the staining and analysis of paraffin sections (Basic Protocol 3) or the immunofluorescence staining of cryopreserved samples (Alternate Protocol 3) to assess pluripotency.

\section{BASIC PROTOCOL 1. Injection of Pluripotent Stem Cells in the Gastrocnemius Muscle}

This protocol describes the procedure for injecting PSCs for a teratoma assay in an immunodeficient mouse model. The procedure is intended to be accessible to researchers with little or no experience with animal models. The gastrocnemius muscle is an ideal injection site for this purpose because it is both easy to work with and has a high efficiency of teratoma formation. The site is highly vascularized, readily accessible for injection without surgery, and easily visible for tracking growth of the teratoma. Before injection, the mice are prepared by removing the hair of the hind limb and disinfecting the injection site. The cells are suspended in Matrigel ${ }^{\mathrm{TM}}$, which has been shown to enhance engraftment and teratoma formation (Prokhorova et. al., 2009). This preparation is further described in Support Protocol 1. We typically achieve a $95-100 \%$ efficiency of teratoma formation using this protocol. 
$1 \times 10^{6}$ PSCs suspended in Matrigel ${ }^{\mathrm{TM}}$ (see Support Protocol 1), kept on ice

Disinfectant (not ethanol-based)

Immunodeficient mice: NOD-SCID IL2Rgammanull (NSG)

Anesthetic: isoflurane (2-chloro-2-(difluoromethoxy)-1,1,1-trifluoro-ethane; Isothesia, Butler Schein ${ }^{\circledR}$ cat. no. 029405)

Butler Schein ${ }^{\circledR}$ - 855-472-4838, Fax: 888-329-3861, https://www.henryscheinvet.com

Iodine solution

Isopropyl alcohol wipe or $70 \%$ ethanol

Insulin syringes $(29$ Gauge $\times 1 / 2$ " needle 3/10cc, Terumo Medical cat. no. SS30M2913)

Terumo Medical - 2101 Cottontail Lane, Somerset, NJ 08870, 800-888-3786, Fax:

800-411-5870, http://www.terumomedical.com

Anesthesia unit or knockdown chamber

$37^{\circ} \mathrm{C}$ heating pad

Electric clippers

Surgical station

Surgical drape

Hair removal cream

Surgical tape

\section{Prepare mice and workstation}

1 Prepare the PSCs for injection (Support Protocol 1) in insulin syringes and keep them on ice.

It is important to keep samples on ice to preserve the viability of the PSCs and prevent the Matrigel $^{\mathrm{TM}}$ from solidifying.

2 Use a disinfectant that is not ethanol-based to clean the inside of the knockdown chamber and the lab bench.

3 Place the mice in the knockdown chamber and anesthetize them.

We use isoflurane vaporized in oxygen at $2-3 \%$ to induce anesthesia and $1-2 \%$ to maintain it once the mice are unconscious. We also recommend using a $37^{\circ} \mathrm{C}$ heating pad to prevent hypothermia.

4 Meanwhile, prepare a surgical station with a sterile surgical drape and a way for providing anesthetic air flow, preferably with a nose cone.

5 When the mice are unconscious and their breathing rate drops to about 1 breath/ second, confirm sufficient level of anesthesia by unresponsiveness to a toe pinch. After the mice are anesthetized, remove the fur at the injection site if you 
lack access to nude immunodeficient mice. This helps visualize the injection site and keeps it clean. First, shave the ventral surface of the hind limb using electric clippers. Next, apply hair removal cream for $1 \mathrm{~min}$ and wipe off the remaining hair using gauze or a paper towel.

\section{Inject PSCs}

6 Place the anesthetized mouse on the surgical station with its nose in the nose cone to allow anesthetic airflow. It may help to secure the forelimbs and head using surgical tape (Fig. 1A).

7 Wipe the skin at the injection site with iodine solution, then with an isopropyl alcohol wipe or a paper towel soaked with $70 \%$ ethanol.

8 Get the limb in position for injection by gently pinching the animal's paw, without pulling the limb, using the thumb and index finger of your nondominant hand (Fig. 1B).

9 Use your middle finger to support the gastrocnemius muscle and move it slightly ventral. By doing so you will be able to fix the muscle, giving you easier access with the needle (Fig. 1C).

10 While maintaining this position, slowly inject $50 \mu \mathrm{l}$ of the cell suspension intramuscularly (Fig. 1D).

11 Keep the mice under anesthesia for 10-15 minutes after injection to make sure that the cell mixture remains localized to the injection site.

This waiting time allows Matrigel ${ }^{\mathrm{TM}}$ to solidify and form an injection plug that enhances cell engraftment. Continue keeping the mice on a heating pad for best recovery.

\section{Track mice post-injection}

12 Monitor the animals for 6-8 weeks afterward to confirm that a mass is growing at the injection site and that the animals are healthy.

Take caution to prevent the immunodeficient mice from getting sick by providing appropriate housing conditions (autoclaved cages and antibiotics added to the drinking water).

13 Sacrifice the animals and explant the teratomas (Basic Protocol 2). It is best to do this when the teratoma is no larger than $1 \mathrm{~cm}^{3}$, or earlier if the animal has visible distress, pain, or illness.

Obtain your institution's protocols for laboratory animal care and make any necessary adjustments to this protocol. Institution-specific rules may supersede the animal practices or experimental endpoints suggested here. 


\section{SUPPORT PROTOCOL 1. Preparation of Pluripotent Stem Cells for Injection}

This protocol describes the harvesting and preparation of PSCs for injection with Matrigel ${ }^{\mathrm{TM}}$. The selection of stable PSC lines and careful preparatory steps will determine the success of teratoma formation. Separate cell harvesting methods are provided for human and mouse cell lines.

\section{Materials}

Culture or frozen stock of PSCs

Dulbecco's phosphate-buffered saline (PBS), without calcium and magnesium (Life Technologies cat. no. 14190)

Life Technologies - 3175 Staley Road, Grand Island, NY 14072, 800-955-6288, Fax: 800-331-2286, https://www.lifetechnologies.com

Human cell dissociation medium (see recipe)

Human PSC culture medium (Essential 8 Medium, Life Technologies cat. no. A1517001)

Trypsin - ethylenediamine tetraacetic acid (EDTA) (TrypLE ${ }^{\mathrm{TM}}$ Express Enzyme, Life Technologies cat. no. 12605010)

Mouse PSC culture medium with 10\% fetal bovine serum (FBS)

Matrigel $^{\mathrm{TM}}$ matrix growth factor reduced, phenol red-free (BD Biosciences cat. no. $356231)$

BD Biosciences - 2350 Qume Drive, San Jose, CA 95131, 877-232-8995, http:// www.bdbiosciences.com/

10-cm cell culture plates

$15 \mathrm{ml}$ tubes

Centrifuge

Insulin syringes ( 29 Gauge $\times 1 \frac{1}{2}$ needle $3 / 10 \mathrm{cc}$, Terumo Medical cat. no. SS30M2913)

\section{Harvest the pluripotent stem cells}

\section{Human PSC harvesting - EDTA dissociation}

1a Aspirate the medium from the culture plate. Rinse the plate with 5-6 $\mathrm{ml}$ of calcium and magnesium-free PBS. Repeat the wash a second time.

Calcium and magnesium will inhibit dissociation, so it is important to conduct these wash steps to remove the salts from the plate. Add PBS slowly to the wall of the plate to avoid agitating the colonies.

2a Add 2-3 $\mathrm{ml}$ of the human cell dissociation medium containing EDTA and let it sit for 3-5 minutes at room temperature. 
A longer incubation time will result in smaller cell clusters. We do not dissociate human PSCs into single cells because teratoma formation efficiency is higher when injecting small cell clusters.

3a Gently aspirate the dissociation medium without disturbing the cells on the plate. Add $4-5 \mathrm{ml}$ of human cell culture media rapidly by directly pipetting to the plate surface in order to dislodge the colonies from the plate.

4a Quickly collect the cell suspension into a $15 \mathrm{ml}$ tube before the cells can reattach to the plate.

After the calcium and magnesium salts in the media saturate the EDTA, cells will begin reattaching to the plate.

\section{Mouse PSC harvesting - trypsin digest}

1b Aspirate the medium from the cell culture plate. Rinse the plate twice with PBS to remove any residual FBS from the culture.

FBS will inhibit the trypsin digest.

2b Add $2 \mathrm{ml}$ of Trypsin-EDTA and incubate at $37^{\circ} \mathrm{C}$ for $3-5 \mathrm{~min}$, or until the colonies start to lift off the plate. Pipette the trypsin solution up and down to dislodge cells in the places where colonies are still attached.

3b Stop trypsin digestion after cells are detached by adding 5-7 $\mathrm{ml}$ of mouse PSC culture media with FBS.

Leaving the cells in the trypsin solution for too long (>10 min) will decrease cell viability. Neutralize the reaction with FBS as soon as the cells have dissociated from the plate.

4b Pipette up and down to mix the two solutions and collect in a $15 \mathrm{ml}$ tube.

\section{Prepare injection mixture}

5 Set aside a small volume of the harvested cells and use your preferred method to determine the cell count.

6 Meanwhile, centrifuge the harvested cells for $5 \mathrm{~min}$ at $300 \times g, 4^{\circ} \mathrm{C}$ and aspirate the supernatant to remove the residual dissociation solution or enzyme.

$7 \quad$ Dilute enough thawed growth factor reduced Matrigel $^{\mathrm{TM}}$ (50 $\mu \mathrm{l}$ per injection) and keep on ice.

Matrigel $^{\mathrm{TM}}$ is often stored at $-20^{\circ} \mathrm{C}$ or $-80^{\circ} \mathrm{C}$. For best performance, thaw the Matrigel ${ }^{\mathrm{TM}}$ stock at $4^{\circ} \mathrm{C}$ overnight before using it for injections. It is very important to keep the stock and diluted solutions on ice as they will rapidly solidify at room temperature.

8 Use $1 \times 10^{6}$ cells per injection. Resuspend the centrifuged cells in $50 \mu$ of the prepared Matrigel $^{\mathrm{TM}}$ solution for every $1 \times 10^{6}$ cells and keep on ice. 
$9 \quad$ Using an insulin syringe, slowly draw $50 \mu \mathrm{l}$ of the cell suspension and immediately place on ice.

Drawing the mixture slowly will prevent cell shearing and improve the efficiency of teratoma formation.

\section{BASIC PROTOCOL 2. Excision and Fixation of Teratoma for Paraffin Embedding}

This protocol provides step-by-step descriptions and images for the excision of a teratoma from the gastrocnemius injection site.

After excision, the samples are fixed in paraformaldehyde and embedded in paraffin. Paraformaldehyde preserves the tissue by forming protein-protein cross links (FraenkelConrat and Olcott, 1948). Fixation and paraffin embedding preserves tissue morphology during sectioning and allows for the high resolution of tissue structures for histological analysis (Buchwalow and Böcker, 2010). However, the procedure also masks antigens and requires the performance of a heat-induced or enzymatic antigen retrieval step if antibody staining is to be performed.

\section{Materials}

Mice with teratoma

4\% (w/v) paraformaldehyde (PFA) in PBS

$70 \%, 90 \%, 95 \%$, and $100 \%(\mathrm{v} / \mathrm{v})$ ethanol solutions

Xylene

Paraffin

Surgical scissors

Surgical forceps

Falcon tubes

Immunohistochemistry cassettes

Microtome

Microscope slides

\section{Excise the teratoma}

1 Sacrifice the mouse in accordance with institutional regulations.

One effective and humane method is to first anesthetize the mouse and then dislocate the cervical vertebrae. Place the mouse face down, apply pressure at the neck using a finger or rod, and pull the tail with enough force to feel the vertebrae dislocate.

2 Pin down the hind limbs so that they are stretched at a 45-degree angle away from the torso and the ventral surface of the hind limb is visible (Fig. 2A). 
3 Using surgical scissors, make the first incision near the foot at the Achilles tendon. (Fig. 2B).

4 Starting from the initial incision, continue cutting the skin along the center line of the tumor (Fig. 2C). Cut away the muscle fascia and any other connective tissue attaching the skin to the tumor.

5 The teratoma may be inside one final layer of connective tissue. Grab hold of this layer using surgical forceps (Fig. 2D).

6 Dissect until the teratoma mass is fully exposed (Fig. 2E).

$7 \quad$ Hold the teratoma gently with forceps and dissect away the connective tissue between it and the leg. (Fig. 2F).

Fix the tissue

8 Transfer the teratomas into labeled tubes with approximately 10 times the tissue volume of $4 \%$ PFA and fix overnight at $4{ }^{\circ} \mathrm{C}$.

\section{Embed specimens in paraffin}

9 After overnight fixation, transfer the teratomas into $70 \%$ ethanol for 1 hour to begin to dehydrate the samples.

10 Keep transferring into increasing concentrations of ethanol $-90 \%$ for 1 hour, $95 \%$ for 1 hour, and $100 \%$ for $1-2$ hours.

11 Remove the teratomas from the ethanol and allow excess ethanol to evaporate before proceeding.

12 Transfer the specimens to xylene and keep at room temperature for 1 hour. Repeat in fresh xylene for another 1 hour.

Caution: Xylene is a volatile toxic substance and should be handled carefully. Perform this step in a chemical fume hood and dispose of xylene in a hazardous waste container.

13 Place the teratomas in labeled immunohistochemistry cassettes.

14 Heat paraffin to $60^{\circ} \mathrm{C}$ to form a liquid and add to the cassettes containing the specimens. The paraffin will harden around the tissue as it cools.

The paraffin-embedded teratomas are very stable and can be stored for a long period of time at room temperature. [*Au: months? Years?]

\section{Sectioning samples}

15 Section the teratomas into 4-6 $\mu \mathrm{m}$ serial sections using a microtome.

For a detailed protocol on sectioning paraffin embedded samples, see Zeller, 2001.

16 Mount the sections onto microscope slides for subsequent analysis. 


\section{ALTERNATE PROTOCOL 2. Cryopreservation of Teratomas for Immunofluorescence Staining}

This protocol describes an alternate method for preserving teratomas by freezing the tissue and storing it at $-80^{\circ} \mathrm{C}$. While PFA-fixed and paraffin-embedded slices can be processed for immunofluorescence staining, the results can vary due to antigen masking and autofluorescence. Cryopreservation, however, is better at preserving tissue antigens and can improve immunofluorescence resolution (Fischer et al., 2008). It also requires fewer processing steps such as dehydration and rehydration, and antigen retrieval is not necessary because of the superior antigen availability. The disadvantage of using cryopreservation over paraffin embedding is that the tissue sections are less stable and do not retain their original morphology with high fidelity.

\section{Materials}

Excised teratomas fixed in PFA

$30 \%(w / v)$ sucrose in PBS

Optimum cutting temperature medium (OCT; Electron Microscopy Sciences cat. no. 62550-01)

Electron Microscopy Sciences - P.O. Box 550, 1560 Industry Road, Hatfield, PA 19440, 800-523-5874, Fax: 215-412-8450, https://www.emsdiasum.com/microscopy

Isopropanol

Dry ice

Glass container for freezing

Cryomolds

Cryostat

Microscope slides (Superfrost ${ }^{\circledR}$ Plus, Fischer Scientific cat. no. 12-550-15)

Fischer Scientific - 800-766-7000, Fax: 800-926-1166, http://www.fishersci.com

Cold air blow dryer

\section{Cryopreserve the teratomas}

1 Obtain excised teratomas fixed overnight in PFA (see Basic Protocol 2 steps 1$5)$.

2 Transfer the fixed teratomas into a $30 \%$ sucrose solution. Store the samples at $4^{\circ} \mathrm{C}$ for about one day. Wait until the sample sinks to the bottom of the tube, which signals that the sucrose concentration in the tissue is equal to that of the solution.

3 Take the samples out of the sucrose solution. 
$4 \quad$ Fill labeled cryomolds with OCT and place the teratomas in the desired orientation for subsequent sectioning.

$5 \quad$ Place a glass container filled with cooled isopropanol on dry ice. Transfer the cryomolds holding the sample to the isopropanol.

To ensure that the isopropanol is at the desired temperature $<-30^{\circ} \mathrm{C}$, either place the container in a $-80^{\circ} \mathrm{C}$ freezer until ready or add $1-2$ blocks of dry ice to the isopropanol before placing on dry ice.

6 Allow the samples ample time to freeze. Remove them from the isopropanol and store at $-80^{\circ} \mathrm{C}$ until cryosectioning.

\section{Cryosection samples}

7 Section the teratomas using a cryostat.

8 Create 3-4 slides of 10-50 $\mu \mathrm{m}$ thickness for antibody staining.

Thicker sections of around 40-50 $\mu \mathrm{m}$ are generally used for observing 3D structures.

9 Let the slides dry on air for 1 hour at room temperature.

10 Dry with cold air for 15 min using a blow dryer.

11 Store slides at $-80^{\circ} \mathrm{C}$ until staining.

\section{BASIC PROTOCOL 3. Analyzing Histology Sections for Germ Layers to Confirm Pluripotency}

Pluripotency can be determined by the presence of all three germ layers from the histology sections of the teratoma. Histological characterization of H\&E slides should always be performed and interpreted by an expert pathologist. In this protocol, we give a broad overview of the tissue morphologies to look for in the samples. Images are provided as examples of the different germ layers present in a teratoma derived from PSCs.

\section{Materials}

Slides with teratoma sections (fixed and paraffin-embedded)

\section{H\&E stain sections}

1 Submit the teratoma sections to a facility that can perform H\&E staining. If the samples must be stained in-house, refer to Cardiff et al., 2014.

\section{Analyze}

2 After staining, give the samples to a trained pathologist for analysis. Examples of teratoma sections with tissues from each germ layer are provided in Figure $3 \mathrm{~A}-\mathrm{C}$. 


\section{ALTERNATE PROTOCOL 3. Analyzing Samples using Immunofluorescence Staining}

In addition to $\mathrm{H} \& \mathrm{E}$ staining, immunofluorescence staining can provide more insight into the specific tissue features present in a teratoma. More detailed identification is possible by targeting antigens from specific tissues of the ectodermal, mesodermal, and endodermal lineages.

\section{Materials}

Slides with teratoma cryosections

PBS

PBS-Triton-X permeabilizing solution (see recipe)

Blocking solution (see recipe)

Primary antibodies, secondary antibodies (see Table 2 in Gertow et al., 2007 for a list of common tissue antigens to stain)

PBS-Tween20 wash solution (see recipe)

Mounting medium

Liquid blocker, Pap pen (Sigma Aldrich cat. no. z377821)

Sigma Aldrich - 800-325-3010, Fax: 800-325-5052, http://www.sigmaaldrich.com

Black staining box

Washing jar with holder for multiple slides

Cover slips

Fluorescence microscope

\section{Permeabilize and block sections}

1 Obtain cryosectioned samples from $-80^{\circ} \mathrm{C}$ storage and let them warm to room temperature (RT).

2 If using different antibodies on the same slide, use a pap pen to isolate different graft sections. Wait 30 minutes until pap pen lines are dry.

3 Rehydrate the samples three times in PBS for 5 min each at RT in the washing jar.

4 Place the samples in PBS-Triton-X permeabilizing solution for $30 \mathrm{~min}$ at RT.

5 Humidify a black staining box by putting water on the bottom and transfer the slides to the box.

6 Gently add $100 \mu \mathrm{l}$ of blocking solution to each slide and keep at RT for 1 hour.

7 Remove blocking solution from the slides by lightly tapping the edges of the slides on a paper towel to knock off any remaining droplets. 


\section{Incubate with primary antibody}

$8 \quad$ Add $80 \mu$ of primary antibody diluted in blocking solution to each slide and incubate overnight at $4^{\circ} \mathrm{C}$ in the humidified staining box.

9 Gently rinse with PBS after incubation by holding the slide at a $45^{\circ}$ angle and slowly pouring PBS over the teratoma section.

10 Wash slides in the PBS-Tween20 wash solution three times for 10 min each at RT.

\section{Incubate with secondary antibody}

11 Put the slides back in the black staining box and incubate with the secondary antibody diluted in blocking solution for 1 hour at RT.

12 Gently rinse with PBS after incubation.

13 Wash slides with PBS-Tween20 three times for 10 min each at RT. Cover the washing jar with aluminum foil to protect the secondary antibody from light exposure.

Prolonged exposure to light will photobleach the fluorophores conjugated to the secondary antibody. To prevent a decrease in staining quality, keep the samples in the dark and covered in aluminum foil after incubation with the secondary antibody.

\section{Mount cover slips}

14 Remove the sample slides from the wash solution and lightly tap to knock off droplets.

15 Pipette $100 \mu \mathrm{l}$ of mounting medium on one side of the sample slide in a line. Place the cover slip at the line and lower it slowly onto the sample slide.

16 After the mounting media hardens for $2-3$ hours at RT, cover the slide box with aluminum foil and store at $4^{\circ} \mathrm{C}$ until analysis.

\section{Analyze immunofluorescence staining}

17 Turn on the immunofluorescence microscope and select filter cubes with suitable wavelengths that will excite the specific fluorophores conjugated to the selected antibodies.

18 Focus the microscope and take images of the slides to confirm presence of cells derived from all three germ layers.

\section{REAGENTS AND SOLUTIONS}

\section{Human cell dissociation medium}

Dilute a $0.5 \mathrm{M}$ EDTA stock in PBS, without calcium and magnesium, for a final concentration of $0.25 \mathrm{mM}$ EDTA. Store at $4^{\circ} \mathrm{C}$ for up to 6 months. 


\section{PBS-Triton-X permeabilizing solution}

PBS containing:

$0.5 \%(\mathrm{v} / \mathrm{v})$ Triton X-100 solution (Sigma Aldrich cat. no. 93443)

Prepare around $200 \mathrm{ml}$ at a time. The Triton X-100 is viscous, so avoid pipetting small volumes. The dilution should be prepared fresh each use.

\section{Blocking solution}

PBS containing:

$0.1 \%$ (v/v) Tween 20 (Sigma Aldrich cat. no. P9416)

$5 \%(\mathrm{v} / \mathrm{v})$ animal serum (The serum should come from the species in which the secondary antibody was raised)

Prepare around $20 \mathrm{ml}$ for one staining procedure. The Tween 20 is viscous, so avoid pipetting small volumes. Keep at $4{ }^{\circ} \mathrm{C}$ and prepare fresh each time.

\section{PBS-Tween20 wash solution}

PBS containing:

$0.1 \%$ (v/v) Tween 20 (Sigma Aldrich cat. no. P9416)

Prepare around $1000 \mathrm{ml}$ for one staining procedure. The Tween 20 is viscous, so avoid pipetting small volumes. Keep at room temperature and prepare fresh each time.

\section{COMMENTARY}

\section{Background Information}

Teratoma formation as a pluripotency assay-Teratomas are benign tumors that form from the growth and differentiation of pluripotent cells (Fekete and Ferrigno, 1952). These tumors contain an assortment of tissue structures from all three germ layers: endodermal, mesodermal, and ectodermal. Early studies observed that teratomas spontaneously formed in the ovaries and testes of certain mouse strains due to the proliferation of pluripotent embryonic cells left over from gonadal development (Fawcett, 1950; Stevens and Little, 1954). These observations linked teratoma formation to the presence of pluripotent cells in an adult animal.

Teratoma formation is now considered a hallmark property of PSCs when they are transplanted into immunodeficient mice (Dressel, 2011). The initial studies to recognize and isolate ESCs used teratomas to confirm pluripotency by differentiation into tissues of all three primary germ layers (Martin, 1981; Thomson et al., 1998). This method was further utilized as a key test of pluripotency with the advent of human and mouse iPSCs (Takahashi and Yamanaka, 2006; Takahashi et al., 2007). One recent theme in stem cell research is the observation of heterogeneity in the gene expression, morphology, and epigenomic profiles of ESCs and iPSCs (Mills et al., 2013; Lister et al., 2011; Narsinh et al., 2011). The most consistent property of PSCs, however, is that they can form teratomas. This is one of the reasons that teratoma formation is widely accepted as the gold standard for assessing 
pluripotency, but is also a potential concern for future PSC-based regenerative medicine if residual undifferentiated PSCs are accidentally introduced (Lee et al., 2013).

The teratoma assay is not without its limitations. It involves a greater waiting time than other methods, and it gives a qualitative, categorical result. In some ways, a categorical yes or no answer is more convenient, but it can be difficult to make definitive conclusions from in-between results, such as the presence of only one or two germ layers. One alternative test is the detection of pluripotency markers. However, this is considered an indirect and less stringent test of pluripotency than the formation of differentiated tissues in teratomas (Daley et al., 2009). Similarly, in vitro differentiation is faster and sensitive, but it is not regarded as a stringent test of pluripotency (Buta et al., 2013). More fundamental and quantitative metrics are on the horizon, such as transcriptome and epigenome analyses (Marks et al., 2012). For now, these methods are expensive and insufficiently characterized for common use. The teratoma assay therefore remains the current standard for assessing pluripotency.

Choice of transplantation site-There are many options for transplantation sites, including the liver (Lees et al., 2007), sub-renal capsule (Prokhorova et. al., 2009), subcutaneous (Cao et al., 2007; Gropp et al., 2012), intramuscular (Plaia et al., 2006; Lee et al., 2009), and intramyocardial (Cao et al., 2006). Reports vary in their suggestions of optimal injection sites. One study found that there was little difference between teratoma formation efficiency in different injection sites (Gutierrez-Aranda et al., 2010). Another suggested that there were differences and reported significantly greater teratoma efficiency in the liver than a subcutaneous injection (Cooke et al., 2006). It was also shown that teratoma assays using Matrige ${ }^{\mathrm{TM}}$ varied in success depending on the injection site (Prokhorova et al., 2009). Although the same study observed the lowest efficiency in hind limb intramuscular injections (15\%), we consistently achieve high (95-100\%) efficiency at the same site. This disparity is a common occurrence in the literature because of the variety of methods labs use to perform teratoma assays (Müller et al., 2010).

To remain accessible and relevant to entry level researchers, this protocol uses the gastrocnemius muscle injection site for its teratoma formation efficiency and ease of access for cell grafting and explanting.

\section{Critical Parameters}

Cell line selection-Human and mouse ESCs should be harvested at lower passage numbers ( $<40$ and $<20$, respectively) because their pluripotency decreases in vitro over time (Park et al, 2008; Xie et al., 2011; Li et al., 2007). For iPSCs, however, it is recommended that the lines are at a later passage ( $>20)$, to give them more time to reach a stable pluripotent phenotype (Koehler et al., 2011).

An in vitro test for pluripotency markers can help determine if a PSC line is likely to form a teratoma in vivo. One can immunostain for Oct4, Sox2, and Nanog in both human and mouse PSC cultures to assess for pluripotency (Martí et al., 2013). 
Integrity of injection sample-Keep the cells at $4^{\circ} \mathrm{C}$ on ice after they have been harvested. Preserve cell viability by drawing the sample slowly into the syringe and expelling slowly into the injection site.

Matrigel ${ }^{\mathrm{TM}}$ should be thawed at $4{ }^{\circ} \mathrm{C}$ overnight and always be kept on ice. Although Matrigel $^{\mathrm{TM}}$ can greatly improve teratoma formation efficiency, it will solidify and prevent any cells from being injected if it is not kept cold at all times after it is mixed in.

Animal handling-The immunodeficient mice should be prepared before injection, as detailed in Basic Protocol 1. Careful disinfection and sanitary techniques will prevent disease and mouse mortality. Sacrifice the mouse before a teratoma grows larger than $1 \mathrm{~cm}^{3}$.

\section{Troubleshooting}

[Table 1]

\section{Anticipated Results}

By 3-4 weeks into the experiment, teratoma growth should be visible in the hind limb. They are typically ready for explantation by 5-7 weeks. Although different cell lines can vary, most of the time, teratoma formation efficiency will be between 95-100\%. The efficiency can decrease if the researcher chooses to forgo using Matrigel ${ }^{\mathrm{TM}}$ as a support matrix or uses a fewer number of cells than as suggested here.

Results can vary between ESCs and iPSCs. In one study, human iPSCs were found to produce teratomas more efficiently and rapidly than human ESCs (Gutierrez-Aranda et al., 2010). The maintenance of iPSC cultures can select for faster growing cells or those with modifications such as tumor suppressor gene deletions, which are associated with a number of iPSC lines (Laurent et al., 2011). Keep in mind that iPSC teratomas might be ready at 5-6 weeks and ESC teratomas at 6-7 weeks.

Stained slides of teratoma sections should show tissues derived from all three germ layers. The three different tissue lineages may not appear on the same slide, but it is not a problem if other sections from the same teratoma contain one or more of the other lineages. A few observable tissues derived from each germ layer are listed below.

Endodermal: gastrointestinal cells (paneth cells, goblet cells), pancreatic tissue, mucinous glandular epithelium, respiratory epithelium, thyroid tissue

Mesodermal: cartilage, bone, skeletal muscle, smooth muscle, adipose tissue, lymphatic tissue

Ectodermal: neuroectodermal tissue, squamous epithelium, sebaceous glands, epidermis

It is important to differentiate between the mouse host tissues and the grafted PSC-derived tissues. This is easier with human PSCs compared to mouse PSCs. The expertise of a trained pathologist is especially recommended for this reason. One should exclude tissues at the boundary, where it is harder to distinguish the origin of fatty connective tissue and muscle. Additionally, inclusion bodies of the host may be found inside the teratoma and can confound interpretation. The gastrocnemius area has host tissues such as skin, muscle, and 
blood vessels. Among the types of tissues found in the injection site, the graft tissues will stand out distinctively at the site.

\section{Time Considerations}

Teratoma formation takes around 5-7 weeks with this protocol. Staining and analysis will add another week before a conclusion can be reached about PSC pluripotency. Due to the long-term nature of the experiment, success will depend on careful preparation and selection of cell lines and mice.

Cell culture-It is important to plan ahead for the time it takes to culture the PSCs before they are ready for harvesting. Cells should be $70-80 \%$ confluent and exhibit normal colony morphology. This usually takes $2-3$ days when passaging from a growing culture. It may take a little longer, about 3-4 days, for cells plated from a frozen stock.

Immunodeficient mice-The mice should be between 6-8 weeks old and must remain in a clean animal facility throughout the teratoma assay duration.

Teratoma formation-Cell harvesting and injections in the gastrocnemius muscle can be completed in a few hours. The cells should be injected as soon as possible after harvesting, but we have also had good results when the cells are kept on ice for up to an hour postharvest while the mice are being prepared. It is possible to perform 10-15 injections in a span of 4-5 hours. With $1 \times 10^{6}$ cells per injection, teratomas should be ready for harvesting in 5-7 weeks.

Teratoma explantation-Explanting a teratoma from the gastrocnemius does not require much time due to the ease of accessing the site. Each sample can be processed in 5-10 minutes.

Tissue preservation and analysis-Both tissue preservation protocols provided require an overnight fixation in PFA. Paraffin embedding requires 6-7 additional hours of preparation consisting of hour-long incubations. Cryopreservation only has one additional overnight incubation before sectioning. Both tissue preservation protocols can be performed on many samples in parallel using a staining box.

Analysis turnaround time can vary depending on whether it is in-house or outsourced. Again, it is highly recommended that a trained pathologist analyze the histology sections.

\section{Acknowledgments}

We thank B. Wu and Dr. J. Gold for critical reading of the manuscript and funding support from National Institutes of Health (NIH) R01 HL113006, NIH U01 HL099776; California Institute for Regenerative Medicine (CIRM) TR3-05556 and CIRM DR2-05394 (J.C.W.). We also thank Dr. Andrew J. Connolly, Department of Pathology, Stanford University School of Medicine, for providing histological analysis and explanation and Dr. J. Riegler for immunofluorescence staining protocol details. 


\section{LITERATURE CITED}

Ben-David U, Mayshar Y, Benvenisty N. Virtual karyotyping of pluripotent stem cells on the basis of their global gene expression profiles. Nat Protoc. 2013; 8:989-997. [PubMed: 23619890]

Bhattacharya B, Miura T, Brandenberger R, Mejido J, Luo Y, Yang AX, Joshi BH, Ginis I, Thies RS, Amit M, Lyons I, Condie BG, Itskovitz-Eldor J, Rao MS, Puri RK. Gene expression in human embryonic stem cell lines: unique molecular signature. Blood. 2004; 103:2956-2964. [PubMed: 15070671]

Bock C, Kiskinis E, Verstappen G, Gu H, Boulting G, Smith ZD, Ziller M, Croft GF, Amoroso MW, Oakley DH, Gnirke A, Eggan K, Meissner A. Reference Maps of human ES and iPS cell variation enable high-throughput characterization of pluripotent cell lines. Cell. 2011; 144:439-452. [PubMed: 21295703]

Brivanlou AH, Gage FH, Jaenisch R, Jessell T, Melton D, Rossant J. Stem cells. Setting standards for human embryonic stem cells. Science. 2003; 300:913-916. [PubMed: 12738841]

Buchwalow, IH.; Böcker, W. Immunohistochemistry: Basics and Methods. Heidelberg, Germany: 2010. Probes Processing in Immunohistochemistry; p. 19-29.

Buta C, David R, Dressel R, Emgård M, Fuchs C, Gross U, Healy L, Hescheler J, Kolar R, Martin U, Mikkers H, Müller FJ, Schneider RK, Seiler AEM, Spielmann H, Weitzer G. Reconsidering pluripotency tests: do we still need teratoma assays? Stem Cell Res. 2013; 11:552-562. [PubMed: 23611953]

Cao F, Lin S, Xie X, Ray P, Patel M, Zhang X, Drukker M, Dylla SJ, Connolly AJ, Chen X, Weissman IL, Gambhir SS, Wu JC. In vivo visualization of embryonic stem cell survival, proliferation, and migration after cardiac delivery. Circulation. 2006; 113:1005-1014. [PubMed: 16476845]

Cao F, van der Bogt KEA, Sadrzadeh A, Xie X, Sheikh AY, Wang H, Connolly AJ, Robbins RC, Wu JC. Spatial and temporal kinetics of teratoma formation from murine embryonic stem cell transplantation. Stem Cells Dev. 2007; 16:883-891. [PubMed: 17896868]

Cardiff RD, Miller CH, Munn RJ. Manual hematoxylin and eosin staining of mouse tissue sections. Cold Spring Harb Protoc. 2014 pdb.prot073411.

Cooke MJ, Stojkovic M, Przyborski SA. Growth of teratomas derived from human pluripotent stem cells is influenced by the graft site. Stem Cells Dev. 2006; 15:254-259. [PubMed: 16646671]

Daley GQ, Lensch MW, Jaenisch R, Meissner A, Plath K, Yamanaka S. Broader implications of defining standards for the pluripotency of iPSCs. Cell Stem Cell. 2009; 4:200-1. author reply 202. [PubMed: 19265657]

Dressel R. Effects of histocompatibility and host immune responses on the tumorigenicity of pluripotent stem cells. Semin Immunopathol. 2011; 33:573-591. [PubMed: 21461989]

Fawcett DW. Bilateral ovarian teratomas in a mouse. Cancer Res. 1950; 10:705-707. [PubMed: 14783767]

Fekete E, Ferrigno MA. Studies on a transplantable teratoma of the mouse. Cancer Res. 1952; 12:438440. [PubMed: 14936010]

Fischer AH, Jacobson KA, Rose J, Zeller R. Cryosectioning tissues. CSH Protoc. 2008; 2008 pdb.prot4991.

Fraenkel-Conrat H, Olcott HS. The reaction of formaldehyde with proteins; cross-linking between amino and primary amide or guanidyl groups. J Am Chem Soc. 1948; 70:2673-2684. [PubMed: 18876976]

Gertow K, Przyborski S, Loring JF, Auerbach JM, Epifano O, Otonkoski T, Damjanov I, AhrlundRichter L. Isolation of human embryonic stem cell-derived teratomas for the assessment of pluripotency. Curr Protoc Stem Cell Biol. 2007; 3:B:1B.4:1B.4.1-1B.4.29.

Gropp M, Shilo V, Vainer G, Gov M, Gil Y, Khaner H, Matzrafi L, Idelson M, Kopolovic J, Zak NB, Reubinoff BE. Standardization of the teratoma assay for analysis of pluripotency of human ES cells and biosafety of their differentiated progeny. PLoS One. 2012; 7:e45532. [PubMed: 23049812]

Gutierrez-Aranda I, Ramos-Mejia V, Bueno C, Munoz-Lopez M, Real PJ, Mácia A, Sanchez L, Ligero G, Garcia-Parez JL, Menendez P. Human induced pluripotent stem cells develop teratoma more 
efficiently and faster than human embryonic stem cells regardless the site of injection. Stem Cells. 2010; 28:1568-1570. [PubMed: 20641038]

Hentze H, Soong PL, Wang ST, Phillips BW, Putti TC, Dunn NR. Teratoma formation by human embryonic stem cells: evaluation of essential parameters for future safety studies. Stem Cell Res. 2009; 2:198-210. [PubMed: 19393593]

Karlsson C, Emanuelsson K, Wessberg F, Kajic K, Axell MZ, Eriksson PS, Lindahl A, Hyllner J, Strehl R. Human embryonic stem cell-derived mesenchymal progenitors--potential in regenerative medicine. Stem Cell Res. 2009; 3:39-50. [PubMed: 19515621]

Kim JB, Zaehres H, Wu G, Gentile L, Ko K, Sebastiano V, Araúzo-Bravo MJ, Ruau D, Han DW, Zenke M, Schöler HR. Pluripotent stem cells induced from adult neural stem cells by reprogramming with two factors. Nature. 2008; 454:646-650. [PubMed: 18594515]

Koehler KR, Tropel P, Theile JW, Kondo T, Cummins TR, Viville S, Hashino E. Extended passaging increases the efficiency of neural differentiation from induced pluripotent stem cells. BMC Neurosci. 2011; 12:82. [PubMed: 21831300]

Kooreman NG, Wu JC. Tumorigenicity of pluripotent stem cells: biological insights from molecular imaging. J R Soc Interface. 2010; 7(Suppl 6):S753-63. [PubMed: 20880852]

Lan F, Lee AS, Liang P, Sanchez-Freire V, Nguyen PK, Wang L, Han L, Yen M, Wang Y, Sun N, Abilez OJ, Hu S, Ebert AD, Navarrete EG, Simmons CS, Wheeler M, Pruitt B, Lewis R, Yamaguchi Y, Ashley EA, Bers DM, Robbins RC, Longaker MT, Wu JC. Abnormal calcium handling properties underlie familial hypertrophic cardiomyopathy pathology in patient-specific induced pluripotent stem cells. Cell Stem Cell. 2013; 12:101-113. [PubMed: 23290139]

Laurent LC, Ulitsky I, Slavin I, Tran H, Schork A, Morey R, Lynch C, Harness JV, Lee S, Barrero MJ, Ku S, Martynova M, Semechkin R, Galat V, Gottesfeld J, Izpisua Belmonte JC, Murry C, Keirstead HS, Park HS, Schmidt U, Laslett AL, Muller FJ, Nievergelt CM, Shamir R, Loring JF. Dynamic changes in the copy number of pluripotency and cell proliferation genes in human ESCs and iPSCs during reprogramming and time in culture. Cell Stem Cell. 2011; 8:106-118. [PubMed: 21211785]

Lee AS, Tang C, Cao F, Xie X, van der Bogt K, Hwang A, Connolly AJ, Robbins RC, Wu JC. Effects of cell number on teratoma formation by human embryonic stem cells. Cell Cycle. 2009; 8:26082612. [PubMed: 19597339]

Lee AS, Tang C, Rao MS, Weissman IL, Wu JC. Tumorigenicity as a clinical hurdle for pluripotent stem cell therapies. Nat Med. 2013; 19:998-1004. [PubMed: 23921754]

Lees JG, Lim SA, Croll T, Williams G, Lui S, Cooper-White J, McQuade LR, Mathiyalagan B, Tuch BE. Transplantation of 3D scaffolds seeded with human embryonic stem cells: biological features of surrogate tissue and teratoma-forming potential. Regen Med. 2007; 2:289-300. [PubMed: 17511565]

Li XY, Jia Q, Di KQ, Gao SM, Wen XH, Zhou RY, Wei W, Wang LZ. Passage number affects the pluripotency of mouse embryonic stem cells as judged by tetraploid embryo aggregation. Cell Tissue Res. 2007; 327:607-614. [PubMed: 17216193]

Lister R, Pelizzola M, Kida YS, Hawkins RD, Nery JR, Hon G, Antosiewicz-Bourget J, O’Malley R, Castanon R, Klugman S, Downes M, Yu R, Stewart R, Ren B, Thomson Ja, Evans RM, Ecker JR. Hotspots of aberrant epigenomic reprogramming in human induced pluripotent stem cells. Nature. 2011; 471:68-73. [PubMed: 21289626]

Marks H, Kalkan T, Menafra R, Denissov S, Jones K, Hofemeister H, Nichols J, Kranz A, Stewart AF, Smith A, Stunnenberg HG. The transcriptional and epigenomic foundations of ground state pluripotency. Cell. 2012; 149:590-604. [PubMed: 22541430]

Martí M, Mulero L, Pardo C, Morera C, Carrió M, Laricchia-Robbio L, Esteban CR, Izpisua Belmonte JC. Characterization of pluripotent stem cells. Nat Protoc. 2013; 8:223-253. [PubMed: 23306458]

Martin GR. Isolation of a pluripotent cell line from early mouse embryos cultured in medium conditioned by teratocarcinoma stem cells. Proc Natl Acad Sci U S A. 1981; 78:7634-7638. [PubMed: 6950406]

Masui S, Nakatake Y, Toyooka Y, Shimosato D, Yagi R, Takahashi K, Okochi H, Okuda A, Matoba R, Sharov AA, Ko MSH, Niwa H. Pluripotency governed by Sox2 via regulation of Oct3/4 expression in mouse embryonic stem cells. Nat Cell Biol. 2007; 9:625-635. [PubMed: 17515932] 
Mills JA, Wang K, Paluru P, Ying L, Lu L, Galvão AM, Xu D, Yao Y, Sullivan SK, Sullivan LM, Mac H, Omari A, Jean JC, Shen S, Gower A, Spira A, Mostoslavsky G, Kotton DN, French DL, Weiss MJ, Gadue P. Clonal genetic and hematopoietic heterogeneity among human-induced pluripotent stem cell lines. Blood. 2013; 122:2047-2051. [PubMed: 23940280]

Mitsui K, Tokuzawa Y, Itoh H, Segawa K, Murakami M, Takahashi K, Maruyama M, Maeda M, Yamanaka S. The homeoprotein Nanog is required for maintenance of pluripotency in mouse epiblast and ES cells. Cell. 2003; 113:631-642. [PubMed: 12787504]

Müller FJ, Goldmann J, Löser P, Loring JF. A call to standardize teratoma assays used to define human pluripotent cell lines. Cell Stem Cell. 2010; 6:412-414. [PubMed: 20452314]

Müller FJ, Schuldt BM, Williams R, Mason D, Altun G, Papapetrou EP, Danner S, Goldmann JE, Herbst A, Schmidt NO, Aldenhoff JB, Laurent LC, Loring JF. A bioinformatic assay for pluripotency in human cells. Nat Methods. 2011; 8:315-317. [PubMed: 21378979]

Narsinh KH, Sun N, Sanchez-Freire V, Lee AS, Almeida P, Hu S, Jan T, Wilson KD, Leong D, Rosenberg J, Yao M, Robbins RC, Wu JC. Single cell transcriptional profiling reveals heterogeneity of human induced pluripotent stem cells. J Clin Invest. 2011; 121:1217-1221. [PubMed: 21317531]

Noaksson K, Zoric N, Zeng X, Rao MS, Hyllner J, Semb H, Kubista M, Sartipy P. Monitoring differentiation of human embryonic stem cells using real-time PCR. Stem Cells. 23:1460-1467. [PubMed: 16081663]

Park, Y Bin; Kim, YY.; Oh, SK.; Chung, SG.; Ku, SY.; Kim, SH.; Choi, YM.; Moon, SY. Alterations of proliferative and differentiation potentials of human embryonic stem cells during long-term culture. Exp Mol Med. 2008; 40:98-108. [PubMed: 18305403]

Plaia TW, Josephson R, Liu Y, Zeng X, Ording C, Toumadje A, Brimble SN, Sherrer ES, Uhl EW, Freed WJ, Schulz TC, Maitra A, Rao MS, Auerbach JM. Characterization of a new NIH-registered variant human embryonic stem cell line, BG01V: a tool for human embryonic stem cell research. Stem Cells. 2006; 24:531-546. [PubMed: 16293579]

Prokhorova TA, Harkness LM, Frandsen U, Ditzel N, Schrøder HD, Burns JS, Kassem M. Teratoma formation by human embryonic stem cells is site dependent and enhanced by the presence of Matrigel. Stem Cells Dev. 18:47-54. [PubMed: 18393673]

Robinton DA, Daley GQ. The promise of induced pluripotent stem cells in research and therapy. Nature. 2012; 481:295-305. [PubMed: 22258608]

Stevens LC, Little CC. Spontaneous Testicular Teratomas in an Inbred Strain of Mice. Proc Natl Acad Sci U S A. 1954; 40:1080-1087. [PubMed: 16578442]

Takahashi K, Yamanaka S. Induction of pluripotent stem cells from mouse embryonic and adult fibroblast cultures by defined factors. Cell. 2006; 126:663-676. [PubMed: 16904174]

Takahashi K, Tanabe K, Ohnuki M, Narita M, Ichisaka T, Tomoda K, Yamanaka S. Induction of pluripotent stem cells from adult human fibroblasts by defined factors. Cell. 2007; 131:861-872. [PubMed: 18035408]

Thomson JA, Itskovitz-Eldor J, Shapiro SS, Waknitz MA, Swiergiel JJ, Marshall VS, Jones JM. Embryonic stem cell lines derived from human blastocysts. Science. 1998; 282:1145-1147. [PubMed: 9804556]

Xie X, Hiona A, Lee AS, Cao F, Huang M, Li Z, Cherry A, Pei X, Wu JC. Effects of long-term culture on human embryonic stem cell aging. Stem Cells Dev. 2011; 20:127-138. [PubMed: 20629482]

Zeller R. Fixation, embedding, and sectioning of tissues, embryos, and single cells. Curr Protoc Mol Biol. 2001; 14(14.1):14.1.1-14.1.8. [PubMed: 18265109] 

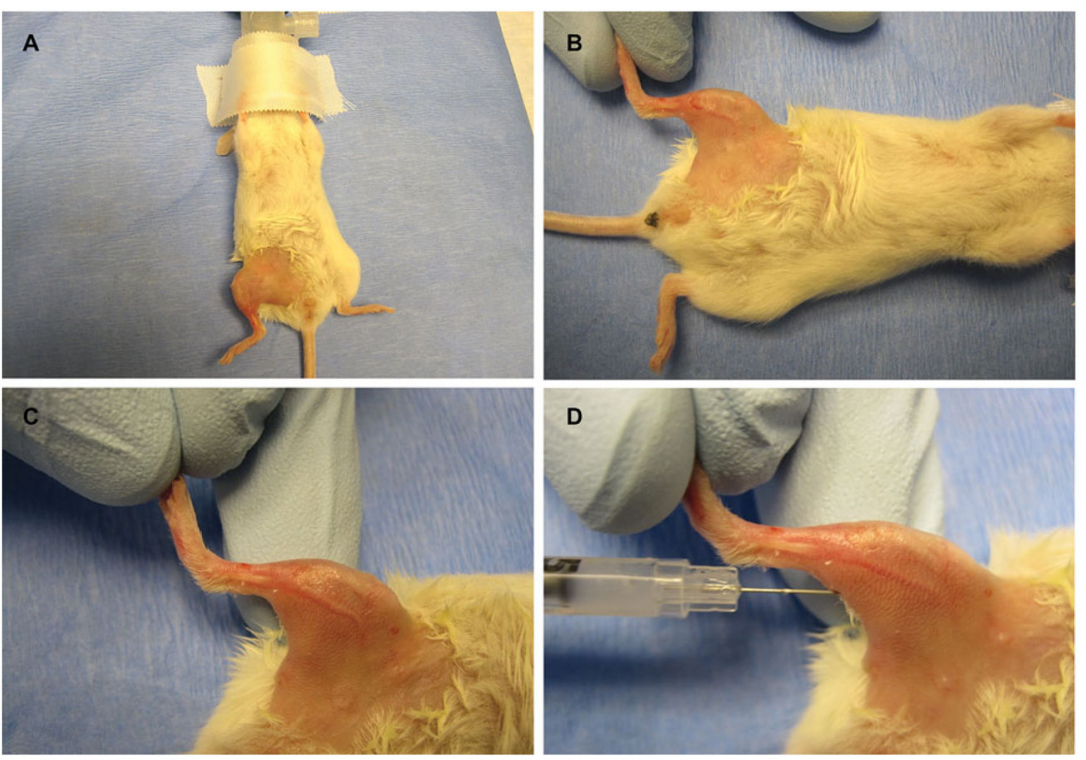

Figure 1.

Schematic for PSC injection in the gastrocnemius muscle of an NSG mouse. (A) Animal is positioned with its nose in the nose cone and ventral surface up. Injection site is shaved and cleaned. (B) Pinch the animal's paw with thumb and forefinger. (C) Support muscle with middle finger and move slightly ventral. (D) Inject PSCs into the now visible muscle. 

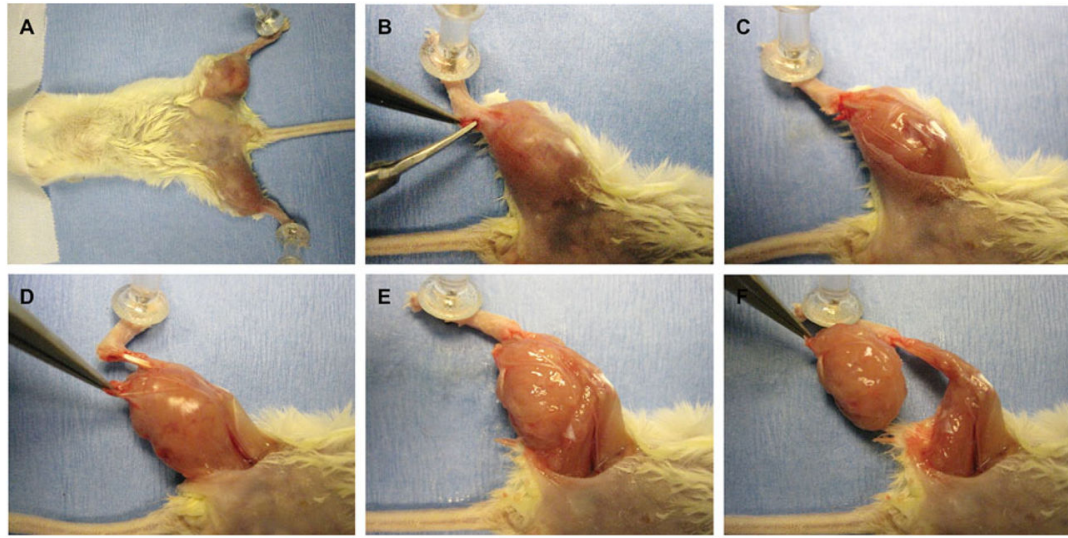

Figure 2.

Procedure of teratoma extraction from the mouse hind limb. (A) Sacrificed mouse pinned down for extraction. (B) First incision made at the Achilles tendon. (C) The skin is sectioned away down the center of the mass. (D) Layer of tissue surrounding teratoma grabbed by forceps. (E) Exposed teratoma after tissue layer is removed. (F) Explanted teratoma after sectioning away connective tissue from the leg. 


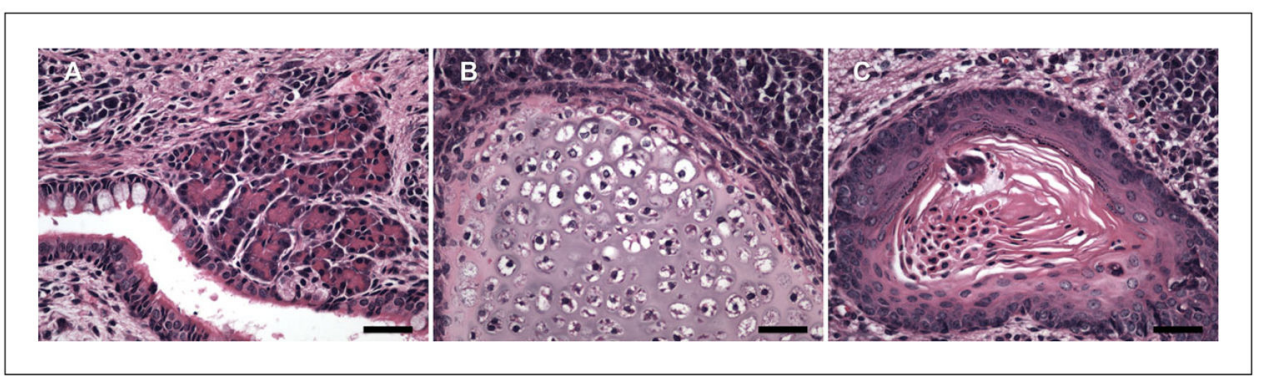

Figure 3.

Paraffin embedded tissue sections from a mouse iPSC teratoma are stained with hematoxylin and eosin. (A) Endoderm-derived glands. (B) Mesoderm-derived cartilage tissue. (C) Ectoderm-derived squamous epithelium. The cell line therefore demonstrates pluripotency by forming tissues from all three germ layers in a teratoma. Scale bar $-50 \mu \mathrm{m}$. 
Table 1

List of Potential Problems when Performing the Teratoma Assay and Troubleshooting Suggestions

\begin{tabular}{|c|c|c|}
\hline Problem & Cause & Solution \\
\hline Mouse mortality & $\begin{array}{l}\text { Mice are too old } \\
\text { Infection due to improper sanitary } \\
\text { conditions }\end{array}$ & $\begin{array}{l}\text { Use mice between } 6-8 \text { weeks old } \\
\text { House the animals in a clean facility and use clean practices when } \\
\text { handling the animals }\end{array}$ \\
\hline No teratoma growth & $\begin{array}{l}\text { Mice are too old } \\
\text { Too few cells were injected }\end{array}$ & $\begin{array}{l}\text { Older mice may not form teratomas as efficiently as mice that are between } \\
6-8 \text { weeks old } \\
\text { Increase the number of cells for the next injections. The optimal cell } \\
\text { concentration can vary depending on the growth characteristics of the cell } \\
\text { line. For a new line, separate injections of } 2 \times 10^{6} \text { and } 4 \times 10^{6} \text { cells in } \\
\text { addition to the recommended } 1 \times 10^{6} \text { will increase the chance for success. }\end{array}$ \\
\hline $\begin{array}{l}\text { Abnormal or } \\
\text { undifferentiated mass } \\
\text { instead of teratoma }\end{array}$ & $\begin{array}{l}\text { Too many cells were injected, } \\
\text { causing central necrosis }\end{array}$ & $\begin{array}{l}\text { Decrease the number of cells for injection. The optimal number can be } \\
\text { found by trying two-fold serial dilutions of } 1 \times 10^{6} \text { cells. }\end{array}$ \\
\hline $\begin{array}{l}\text { Lack of three germ } \\
\text { layers }\end{array}$ & $\begin{array}{l}\text { Inaccurate sectioning of histology } \\
\text { slides } \\
\text { Cells are undifferentiated } \\
\text { Cell line is not pluripotent }\end{array}$ & $\begin{array}{l}\text { Section additional histology slices and confirm the three germ layers } \\
\text { Injection of too many PSCs will hinder differentiation, so the cell number } \\
\text { should be reduced. If there are signs of partially differentiated tissue, wait } \\
\text { longer before excising the teratoma. } \\
\text { High ESC or low iPSC passage number lines can have decreased } \\
\text { pluripotency. Choosing PSCs with good colony morphology and growth } \\
\text { will increase success. Additionally, before performing the teratoma assay, } \\
\text { it is advisable to obtain evidence that the cell line expresses pluripotency } \\
\text { markers in vitro. }\end{array}$ \\
\hline
\end{tabular}

